\title{
PENGARUH WAKTU PEMBERIAN MIKRO ORGANISME LOKAL TERHADAP PERTUMBUHAN DAN HASIL TANAMAN KUBIS (Brasicca oleraceae L.)
}

\author{
Murdaningsih ${ }^{1}$, Yuvensius Jeni ${ }^{2}$ \\ Ningsih_murda@yahoo.co.id \\ Program Studi Agroteknologi, Fakultas Pertanian-Universitas Flores
}

\begin{abstract}
This research aims at finding out the effect of treatment period of local micro organism towards the growth and yield of cabbage plants (Brasicca oleraceae L.) and was conducted in the experiment garden of Faculty of Agriculture Flores University in Lokoboko District, East Ndona Subdistrict, Ende Regency.

The design used in this experiment is Randomized Block Design (RBD), with treatment used is M0 (without LMO treatment), M1 (once in 3 days LMO treatment), M2 (once in 5 days LMO treatment), and M3 (once in 7 days LMO treatment). The variable of the observation in this experiment are total leaves, fresh weight of crops per plant, fresh weight of crops per hectare, the diameter of the crops, fresh weight of residue, and the index of harvest.

The result indicates that with the treatment of the period giving MOL 3 times a day shows the growth increase of plants' total leaf in every period of observation 14hst, $21 \mathrm{hst}, 28 \mathrm{hst}, 35 \mathrm{hst}, 42 \mathrm{hst}$ ). In all result variable showing the good increase to the result, M1 treatment fresh weight crop per plant are $1700 \mathrm{gr}$, fresh weight crop per ha are 68.00 tons, diameter crop are $19.52 \mathrm{~cm}$, fresh weight of residue per plan are $1.94 \mathrm{~kg}$, and harvest index are 46.70, M2 treatment fresh weight crop per plant are $1660 \mathrm{gr}$, fresh weight crops per ha are $1.88 \mathrm{~kg}$, and harvest index are 46.89, M3 treatment fresh weight crop per plant is (1680 gr), fresh weight crop per ha are 67.2 tons, diameter crop are $18.92 \mathrm{~cm}$, fresh weight residue per plant is $(1,88 \mathrm{~kg})$, and harvest index is 47.19 .
\end{abstract}

Key Words: treatment period of local micro organism, cabbage

\section{PENDAHULUAN}

Mikroorganisme adalah organisme yang berukuran sangat kecil biasanya kurang dari $1 \mathrm{~mm}$ sehingga untuk mengamatinya diperlukan alat bantuan mikroskop. Mikroorganisme Lokal (MOL) merupakan bakteri yang ada di sekitar kita dimana berguna untuk menyuburkan tanah, dan berfungsi sebagai perombak bahan organik tanah sehingga unsur hara bagi tanaman dapat tersedia dan sekaligus dapat merubah tekstur tanah menjadi lebih baik (Sofa, 2008). Pada dasarnya bahan utama MOL terdiri dari tiga jenis komponen yaitu, Karbohidrat sumbernya bisa dari 
Murdaningsih: Pengaruh waktu pemberian mikro organisme lokal terhadap pertumbuhan dan hasil tanaman kubis (Brasicca oleraceae L.)

air cucian beras, nasi bekas (nasi basi), singkong, kentang, atau gandum. Glukosa bisa diperoleh dari tetes tebu atau molasse, gula pasir, atau air kelapa, dan Sumber bakteri bisa diperoleh dari buah-buahan yang busuk, seperti tomat, pisang, papaya, dan lain-lain (jakes Sitto, 2008). Pengembangan MOL sangat mudah dilakukan, karena bahan alam yang digunakan sebagai bahan baku pembuatan MOL seperti bonggol pisang, rebung, buah maja, air cucian beras sangat mudah didapatkan.

Hasil survei dari Dinas Pertanian dan Tanaman Pangan Kabupaten Ende untuk tanaman kubis, dari tahun 2009 sampai 2011 produksinya tidak mengalami perubahan yaitu dengan luas lahan 18,50 ha, dan luas panen 16,40 ha, dengan produktivitasnya sebesar 12 ton/ha, hal ini disebabkan oleh berbagai macam faktor penghambat. Salah satu dari sekian banyak permasalahan adalah kurang adanya pemahaman dari petani tentang teknik pemupukan yang baik untuk keberhasilan dalam membudidayakan tanaman kubis, sehingga perlu dilakukan penanganan yang baik dalam usaha pengembangan budidaya tanaman kubis di Kabupaten Ende.
Mikroorganisme non pathogenik yang dieksplor dari berbagai macam bahan organik tersebut mempunyai karakteristik yang berbeda-beda. Mikroorganisme yang dieksplor dari bonggol pisang kepok akan berbeda dengan mikroorganisme yang di eksplor dari rebung, dimana kelebihan dari mikroorganisme bonggol pisang memiliki kandungan 90\% merupakan mikroba Lactobacillus yang mampu mempercepat perombakan bahan organik dalam tanah menjadi unsur hara $\mathrm{N}, \mathrm{P}, \mathrm{K}$ yang lengkap, dapat memperbaiki sifat fisik, kimia, serta biologi tanah, dan sekaligus dapat merangsang perkembangan mikroorganisme lain yang baik untuk pertumbuhan tanaman, misalnya bakteri pengikat nitrogen, bakteri pelarut fosfat, dan mikoriza, (Jakes Sitto, 2010). Mikroorganisme berfungsi sebagai pengurai dari bahan-bahan organik yang berada dalam tanah sehingga berubah menjadi zat hara Nitrogen, Phosfat, Kalium, dan unsur hara makro dan mikro lainya yang dapat dengan mudah diserap oleh tanaman bila dibandingkan dengan jenis EM (Efektif Mikro Organisme) yang lainya, seperti EM4 yang sering dipasarkan di toko pertanian lain. Selain itu, dilihat dari 
Murdaningsih: Pengaruh waktu pemberian mikro organisme lokal terhadap pertumbuhan dan hasil tanaman kubis (Brasicca oleraceae L.)

segi ekonomisnya lebih menguntungkan karena MOL kita dapat dengan mudah membuatnya sendiri karena bahan baku pembuatannya banyak terdapat di alam dan dalam proses pembuatannya tidak membutuhkan waktu yang lama (Jakes Sitto, 2010). Pemanfaatan MOL sebagai bahan stimulan bagi unsur hara tanaman saat ini telah berkembang pesat dengan adanya sistim pertanian saat ini yang lebih mengutamakan ramah lingkungan dan berkelanjutan, karena MOL mampu mengurangi pengaruh negatif pada lingkungan sebab tidak merusak alam, lebih ekonomis, dan ramah ligkungan (Anonim, 2009). Mikroorganisme Lokal merupakan bakteri buatan yang memanfaatkan bahan-bahan alami sebagai perombak bahan organik tanah sehingga dapat merubah sifat fisik, kimia, tanah menjadi lebih baik, sekaligus mampu merubah tekstur tanah juga menjadi lebih baik.

Hasil analisis tanah di kebun percobaan Fakultas Pertanian Universitas Flores memperlihatkan kandungan unsur hara yang rendah, dimana C-organik $1,66 \%, \mathrm{~N}$ total $0,17 \%, \mathrm{C} / \mathrm{N}$ ratio $10 \%, \mathrm{P} 10,94 \%, \mathrm{~K}$ $0,36 \%, \mathrm{Na} 0,20 \%, \mathrm{Ca} 8,32 \%, \mathrm{Mg}$ 0,96\%, pH 6,5c, tekstur lempung berpasir, (Saferius F.K, 2012). Sehingga perlu ditambahkan bahan organik dan MOL sebagai bahan aktif untuk mempercepat proses perombakan bahan organik yang ada di dalam tanah menjadi unsur hara yang lebih baik untuk pertumbuhan dan hasil tanaman kubis.

Suwardji (2007), dalam penelitianya menjelaskan bahwa aplikasi bahan organik kotoran ternak ayam bersamaan dengan aplikasi MOL, dapat mempercepat proses dekomposisi bahan organik kotoran ternak ayam, dan mampu menghasilkan kandungan unsur hara $\mathrm{N}, \mathrm{P}, \mathrm{K}$, yang langsung dapat diserap oleh akar tanaman kubis, karena tanaman kubis banyak membutuhkan unsur hara Nitrogen dan Kalium, sehingga sangat cocok untuk di aplikasikan pada tanaman kubis.

Aplikasi MOL pada bahan organik untuk penanaman kubis memperlihatkan beberapa pengaruh, antara lain perubahan fisik, biologis dan kimia tanah, memperdalam lapisan olah tanah, meningkatkan agregasi tanah, serta memacu pertumbuhan dan produksi tanaman kubis.

Aplikasi MOL pada tanaman kubis akan memungkinkan tanaman kubis tumbuh subur, lebih segar, rasanya lebih enak, lebih cepat dipanen yaitu pada 
Murdaningsih: Pengaruh waktu pemberian mikro organisme lokal terhadap pertumbuhan dan hasil tanaman kubis (Brasicca oleraceae L.)

umur 75 hst, dan mampu menghasilkan produksinya menjadi 40 ton/ha (Jakes Sitto, 2010).

Menurut hasil penelitian Jakes Sito (2010), mengatakan bahwa aplikasi MOL 3 hari sekali pada tanaman kubis dengan kosentrasi 1 liter MOL dicampurkan dengan 15 liter air bersih dan diberikan sebanyak 72 liter MOL selama satu musim tanam dapat meningkatkan hasil panen yang semula 30 ton/ha naik menjadi 50 ton/ha. Oleh karena itu salah satu upaya untuk meningkatkan hasil tanaman kubis adalah dengan penambahan MOL, karena pada dasarnya tanaman kubis sangat membutuhkan unsur hara Nitrogen dan Kalium untuk pertumbuhannya, sebab hasil perombakan MOL terhadap bahan organik kotoran ternak ayam mampu menghasilkan kandungan $\mathrm{N} 2,6 \%, \mathrm{P}$ 2,9\%, dan $\mathrm{K} \quad 3,4 \%$, dengan perbandingan $\mathrm{C} / \mathrm{N}$ ratio $8 / 3$ (zakaria, 2002). Sehingga hal ini sangat cocok untuk diaplikasikan pada tanaman kubis sebagai unsur hara untuk pertumbuhan dan hasil tanaman yang optimal.

Dengan melihat permasalahan yang terjadi dalam usaha budidaya tanaman kubis, dan disamping itu banyak sekali potensi sumber alam yang tersedia untuk bahan baku pembuatan MOL di Kabupaten Ende, maka ini merupakan suatu hal yang perlu diperhatikan oleh Sivitas Akademik dan perlu ditindaklanjuti dalam sebuah penelitian.

\section{METODELOGI PENELITIAN}

\section{Tempat dan Waktu.}

Penelitian ini dilakukan di kebun percobaan Fakultas Pertanian Universitas Flores yang berada di Kelurahan Lokoboko, Kecamatan Ndona, Kabupaten Ende. Dengan jenis tanah lempung berpasir, $\mathrm{pH}$ tanah 6,5, suhu rata-rata $27-31^{\circ} \mathrm{C}$, dan curah hujan berkisar antara $1.000-1.750 \mathrm{~mm}$ per tahun, (Saferius F.K, 2012) Penelitian ini dilakukan selama 7 bulan yaitu dari bulan Juli 2012 - bulan Februari 2013.

\section{Bahan dan Alat}

Bahan yang digunakan adalah benih tanaman kubis F1 Hibrida Grand 22 Tanindo, Pupuk Kandang Ayam, dan MOL yang terbuat dari bonggol pisang, tebu, air cucian beras, air bersih, buah pisang kepok yang masak, dan gula pasir. Alat-alat yang digunakan dalam percobaan ini adalah Cangkul, Parang, Pisau, ember, gembor, mistar, meteran rol, timbangan, buku tulis, buku panduan, dan alat tulis. 
Murdaningsih: Pengaruh waktu pemberian mikro organisme lokal terhadap pertumbuhan dan hasil tanaman kubis (Brasicca oleraceae L.)

Rancangan Penelitian.

Percobaan ini menggunakan Rancangan Acak Kelompok (RAK) dengan 4 perlakuan, yaitu

MO (tanpa perlakuan), M1 (pemberian MOL tiga hari sekali), (M2 pemberian MOL lima hari sekali), M3 pemberian MOL tujuh hari sekali, Setiap perlakuan diulang 5 kali sehingga terdapat 20 unit percobaan.

Pelaksanaan penelitian.

Pembuatan MOL.

Alat-alat untuk pembuatan MOL adalah jirgen, ember, parang, saringan, dan alat ukur literan, bahan yang harus disiapkan adalah, bonggol pisang kepok sebanyak 20 gram, buah pisang kepok masak sebanyak 20 gram, tebu sebanyak 20 gram, air cucian beras yang pertama sebanyak 2 liter, air bersih sebanyak 5 liter, dan gula pasir sebanyak 20 gram, (Jakes Sitto, 2012).

Cara kerjanya bonggol pisang, buah pisang, dan tebu dihancurkan, lalu dicampur bersamaan dengan air cucian beras, air bersih, dan gula pasir. Campuran tersebut diatas dimasukan kedalam ember atau jirgen dan ditutup rapat untuk difermentasikan. Waktu yang diperlukan untuk fermentasi dalam pembuatan MOL adalah selama 2 minggu, setelah difermentasikan, maka tutupanya dapat dibuka. Untuk mengetahui tanda-tanda pembuatan MOL berhasil yaitu dengan tercium aroma asam manis, maka hasil pembuatan MOL tersebut dinyatakan berhasil. Setelah proses fermentasi, maka langkah selanjutnya adalah memisahkan ampas dari larutan hasil fermentasi menggunakan saringan halus dengan ukuran 20 mech. Hasil saringan MOL tersebut dapat langsung digunakan, sedangkan ampasnya dibuang. Dalam sekali pembuatan MOL menghasilkan larutan MOL yang siap pakai sebanyak 7 liter, yang dapat langsung dicampur dengan air bersih sebanyak 105 liter, untuk diaplikasikan pada tanaman atau yang lainya (Jakes Sitto, 2012).

\section{Persiapan tempat persemaian.}

Media persemaian yang digunakan adalah tanah yang dicampur dengan pupuk kandang sapi dengan perbandingan 1:1, lalu diaduk merata, setelah itu media tanah diisi pada kotak persemaian yang sudah disiapkan.

\section{Persiapan Lahan.}

Lahan yang akan digunakan untuk penelitian diolah menggunakan cangkul dengan kedalaman $20-30 \mathrm{~cm}$, setelah itu bersikan gulma dan sisa-sisa akarnya. Pemupukan dasar dilakukan 
Murdaningsih: Pengaruh waktu pemberian mikro organisme lokal terhadap pertumbuhan dan hasil tanaman kubis (Brasicca oleraceae L.)

bersamaan dengan waktu pengolahan lahan, yaitu dengan menggunakan pupuk kandang ayam sebanyak 5 ton/ha, atau $2,28 \mathrm{~kg} /$ petak, lalu dibuat bedengan dengan ukuran 2,4 $\mathrm{m}$ x 1,9 m, dengan jarak tanam 50 x $50 \mathrm{~cm}$, sedangkan jarak antara bedengan dibuat parit selebar $40 \mathrm{~cm}$ sebagai saluran drainase (lampiran1 dan 2).

\section{Penanaman.}

Bibit tanaman kubis yang sudah berumur 1 bulan, dengan jumlah daun sebanyak 4 helai, dipindah ke bedengan dengan jarak tanam $50 \times 50 \mathrm{~cm}$, setiap lubang ditanam satu bibit kubis.

\section{Aplikasi MOL.}

Aplikasi MOL dilakukan sesuai perlakuan dimana untuk perlakuan M1 diaplikasikan 3 hari sekali sebanyak 18 kali pemberian yaitu dari hari ke 3 , hingga hari ke 56 dengan dosis 0,8 liter/petak dalam sekali aplikasi, atau setara dengan 14,4 liter/petak. Untuk perlakuan M2 diaplikasikan 5 hari sekali sebanyak 11 kali pemberian yaitu dari hari ke 5, hingga hari ke 55 dengan dosis 1,31 liter/petak dalam sekali aplikasi, atau setara dengan 14,4 liter/petak, sedangkan untuk perlakuan M3 diaplikasikan 7 hari sekali sebanyak 8 kali yaitu dari hari ke 7, hingga hari ke 56 dengan dosis 1,8 liter/petak dalam sekali aplikasi, atau setara dengan 14,4 liter/petak, sehingga pada setiap perlakuan diatas menggunakan dosis 31578 liter/ha.

\section{Pemeliharaan tanaman.}

Penyiraman dilakukan setiap hari dengan menggunakan gembor, yaitu pada waktu pagi hari atau sore hari. Penyulaman dilakukan pada saat tanaman berumur antara 1 sampai 2 minggu setelah tanam, karena ditemui sekitar 20 tanaman yang mati dan dilakukan pada waktu sore hari agar tanaman tidak layu. Sedangkan untuk penyiangan mulai dilakukan pada waktu tanaman berumur 14 hst, dan dilakukan setiap 2 minggu sekali dengan cara mencabut gulma yang berada disekitar tanaman kubis, agar tidak terjadi persaingan dalam memperebutkan unsur hara, cahaya, dan tempat, tanaman kubis.

\section{Pengendalian Hama.}

Hama yang ditemukan di lapang adalah hama Plutella xylostella yang menyerang bagian daun tanaman pada waktu umur 45 hst, dengan cara melubangi daging daun dengan intesitas serangannya sedang, sehingga dilakukan pengendalian dengan menggunakan pestisida kimia Glensek dengan dosis 1cc/liter air, dan 
Murdaningsih: Pengaruh waktu pemberian mikro organisme lokal terhadap pertumbuhan dan hasil tanaman kubis (Brasicca oleraceae L.)

disemprotkan secara merata pada bagian tanaman yang terserang hama sebanyak satu kali.

\section{Panen}

Tanaman kubis jenis hibrida grand 22 dipanen pada umur 75 hari setelah tanam, dengan tanda-tanda kropnya telah mencapai ukuran maksimum, padat kompak, dan bila ditekan dengan jari tangan berbunyi nyaring. Panen dilakukan hanya sekali untuk seluruh tanaman yang ada, yaitu dengan cara mencabut keseluruhan bagian tanaman.

\section{Parameter Pengamatan}

Parameter yang diamati pada percobaan ini meliputi:

1. Jumlah daun tanaman (helai).

2. Berat segar krop per tanaman (gr).

3. Berat segar krop per ha (ton).

4. Diameter krop (cm).

5. Berat segar Brangkasan per tanaman $(\mathrm{kg})$.

6. Berat segar brankasan per ha (ton)

7. Indeks panen.

\section{Analisis data}

Data yang diperoleh dianalisis menggunakan analisis sidik ragam sesuai dengan rancangan yang digunakan, bila terjadi perbedaan yang nyata terhadap variabel yang diamati maka dilanjutkan dengan uji lanjut BNT taraf $5 \%$ (Gomez K.A Gomez A.A. 1991).

\section{HASIL DAN PEMBAHASAN}

Hasil analisis Statistik menunjukan bahwa waktu pemberian Mikroorganisme Lokal (MOL) berpengaruh sangat nyata terhadap pertumbuhan jumlah daun pada umur 14 hst, 21 hst, 28 hst, 35 hst, 42 hst, dan berpengaruh sangat nyata pula terhadap berat segar krop/tanaman, berat segar krop/ ha, diameter krop, dan berat segar Brangkasan pada umur 75 hst (tabel 4.1).

\section{Pengaruh Waktu Pemberian MOL Pada} Pertumbuhan Tanaman Kubis.

Hasil analisis sidik ragam menunjukan bahwa waktu pemberian Mikro Organisme Lokal (MOL) berpengaruh sangat nyata sampai tidak nyata terhadap pertumbuhan jumlah daun, pada umur 14 hst, 21 hst, 28 hst, 35 hst, dan 42 hst. (Tabel 4.2). 
Murdaningsih: Pengaruh waktu pemberian mikro organisme lokal terhadap pertumbuhan dan hasil tanaman kubis (Brasicca oleraceae L.)

Tabel 4.1. Signifikasi Pengaruh Waktu Penberian MOL terhadap pertumbuhan dan hasil tanaman Kubis.

\begin{tabular}{lll}
\hline NO. & Parameter & Signifikasi \\
\hline 1 & Jumlah Daun 14 hst & $* *$ \\
2 & Jumlah Daun 21 hst & $* *$ \\
3 & Jumlah Daun 28 hst & $* *$ \\
4 & Jumlah Daun 35 hst & $* *$ \\
5 & Jumlah Daun 42 hst & $* *$ \\
6 & Berat Segar Krop/Tanaman & $* *$ \\
7 & Berat Segar Krop/ha & $* *$ \\
8 & Diameter Krop & $* *$ \\
9 & Berat Segar Brankasan/tanaman & $* *$ \\
10 & Berat Segar Brankasan/ha & $* *$ \\
11 & Indeks Panen & $* *$ \\
\hline
\end{tabular}

Keterangan:

HST = Hari Setelah Tanam

$* *$ = Sangat Nyata

Tabel 4.2 Rataan pengaruh waktu pemberian MOL terhadap pertumbuhan tanaman

\begin{tabular}{cclllll}
\hline Variabel & \multirow{2}{*}{ Perlakuan } & \multicolumn{5}{c}{ Umur Pengamatan } \\
\cline { 4 - 6 } & & 14 & 21 & 28 & 35 & 42 \\
\cline { 3 - 6 } Jumlah & M0 & $4,58 \mathrm{c}$ & 6,02 & 6,9 & 8,34 & 9,2 \\
Daun & M1 & $5,72 \mathrm{~b}$ & 7,2 & 9,0 & 10 & 11,72 \\
(Helai) & M2 & $5,20 \mathrm{~b}$ & 7,02 & 7,98 & 8,3 & 10,4 \\
& M3 & 5,26 & 6,56 & 7,54 & 8,72 & 10,11 \\
& BNT 5\% & 0,48 & 0,61 & 0,62 & 0,51 & 0,69 \\
\hline
\end{tabular}

Tabel 4.2 memperlihatkan bahwa pertumbuhan jumlah daun yang terbentuk pada umur tanaman 14 hst pada setiap perlakuan relatif lambat dibandingkan dengan umur tanaman 21 hst, hal ini disebebkan karena pada umur tanaman 14 hst setiap perlakuan masih sedikit jumlah MOL yang diberikan yaitu M1 baru diberikan sebanyak 2 kali yaitu sebesar 8 liter, M2 diberikan sebanyak 2 kali yaitu sebesar
13 liter, dan M3 diberikan masih 1 kali yaitu sebesar 9 liter, sehingga hal inilah yang menyebabkan pertumbuhan jumlah daun pada umur tanaman $21 \mathrm{hst}$ relatif lambat, karena jumlah mikro organisme yang berfungsi merombak bahan organik dalam tanah menjadi unsur hara masih rendah sehingga tanaman mengabsorbsi unsur hara dalam tanah juga masih sedikit. Selain itu juga keadaan sistim perakaran 
Murdaningsih: Pengaruh waktu pemberian mikro organisme lokal terhadap pertumbuhan dan hasil tanaman kubis (Brasicca oleraceae L.)

tanaman yang belum berkembang dengan baik, sebab kondisi tanaman yang masih mudah dan labil, tetapi dengan bertambahnya umur tanaman, maka perkembangan akar tanaman semakin baik sehingga pertumbuhan jumlah daun juga terlihat semakin banyak terbentuk. Hal ini juga diperkuat oleh anonim (2007), yang mengemukakan bahwa serapan akar pada awal pertumbuhan belum mencapai kondisi maksimal di fase vegetatif lambat.

Pada hasil rataan waktu umur tanaman 21 hst terlihat bahwa jumlah daun yang terbanyak adalah perlakuan M1 (3 hari sekali), hal ini terjadi karena banyak dan sedikitnya MOL yang diberikan. Sebab pada perlakuan M1 (3 hari sekali) lebih banyak dibandingkan denga perlakuan M2 (5 hari sekali), dan M3 (7 hari sekali), dimana pada perlakuan M1 banyaknya MOL yang diberikan sebanyak 20 liter pada umur tanaman 21 hst, sedangkan pada umur yang sama pula untuk perlakuan M2, hanya sebesar 13,8 liter dan M3, sebesar 18 liter. Hal ini juga diakibatkan karena semakin banyak MOL yang diberikan pada tanaman, maka semakin banyak pula unsur hara yang terdapat di dalam tanah akibat dari banyaknya jumlah mikroorganisme yang merombak bahan organik menjadi unsur hara yang lengkap yang dibutuhkan untuk pertumbuhan tanaman kubis, sehingga pada umur 21 hst pertumbuhan jumlah daun yang terbentuk antara perlakuan M1, dengan M2, mengalami pertambahan jumlah daun sebesar 0,18 $\%$. Sementara pertumbuhan jumlah daun pada umur 28 hst, dan 35 hst, untuk perlakuan M1, M2, dan M3 juga mengalami peningkatan sekitar 1,02\%, hal ini juga diakibatkan karena perbedaan jumlah dan waktu pemberian MOL pada setiap perlakuan ini, dimana untuk perlakuan M1 pada umur 28, dan 35 hst yang semakin sering diberikan MOL dan semakin banyak jumlah MOL yang diberikan yaitu sebanyak 40 liter, sedangkan untuk perlakuan M2, dan M3, pertumbuhan jumlah daun yang terbentuk sedikit karena pada umur 28 hst, dan 35 hst, jumlah MOL yang diberikan hanya sebesar 27,6 liter, dan 36 liter, sehingga Mikrooganisme kurang bekerja merombak bahan organik dalam tanah menjadi unsur hara yang penting untuk pertumbuhan tanaman. Sedangkan pada umur tanaman 42 hst pertumbuhan jumlah daun yang terbentuk untuk perlakuan M2 (5 hari sekali), dan perlakuan M3 (7 
Murdaningsih: Pengaruh waktu pemberian mikro organisme lokal terhadap pertumbuhan dan hasil tanaman kubis (Brasicca oleraceae L.)

hari sekali), aplikasi MOL lebih sedikit yaitu sebesar 34,4 liter, dan 45 liter pada umur ini dibandingkan dengan perlakuan M1 diberikan sebanyak 48 liter., sebab pada perlakuan M1 dengan semakin sering dan dengan jumlah yang lebih banyak pemberian MOL pada tanaman, maka mikroorganisme berperan aktif mampu mempercepat proses perombakan bahan organik dalam tanah menjadi unsur hara $\mathrm{N}, \mathrm{P}$, $\mathrm{K}$, yang lengkap, dimana unsur $\mathrm{N}$ yang diperlukan tanaman pada fase vegetatif sehingga terlihat peningkatan pada jumlah daun tanaman sebesar 1,28\%.
Hal ini juga diperkuat dari hasil penelitian Jakes Sitto, (2009) mengatakan bahwa pemberian MOL 3 Hari sekali mampu meningkatkan pertumbuhan jumlah daun tanaman kubis sebesar 10-20\%.

\subsection{Variabel hasil}

Berdasarkan hasil analisis sidik ragam, menunjukan bahwa pengaruh waktu pemberian MOL berpengaruh nyata sampai tidak nyata terhadap berat segar krop pertanaman, berat segar krop per ha, diameter krop, berat brangkasan segar pertanaman dan indeks panen yang dihitung pada saat panen.

Tabel 4.3. Rataan pengaruh waktu pemberian MOL terhadap variabel hasil

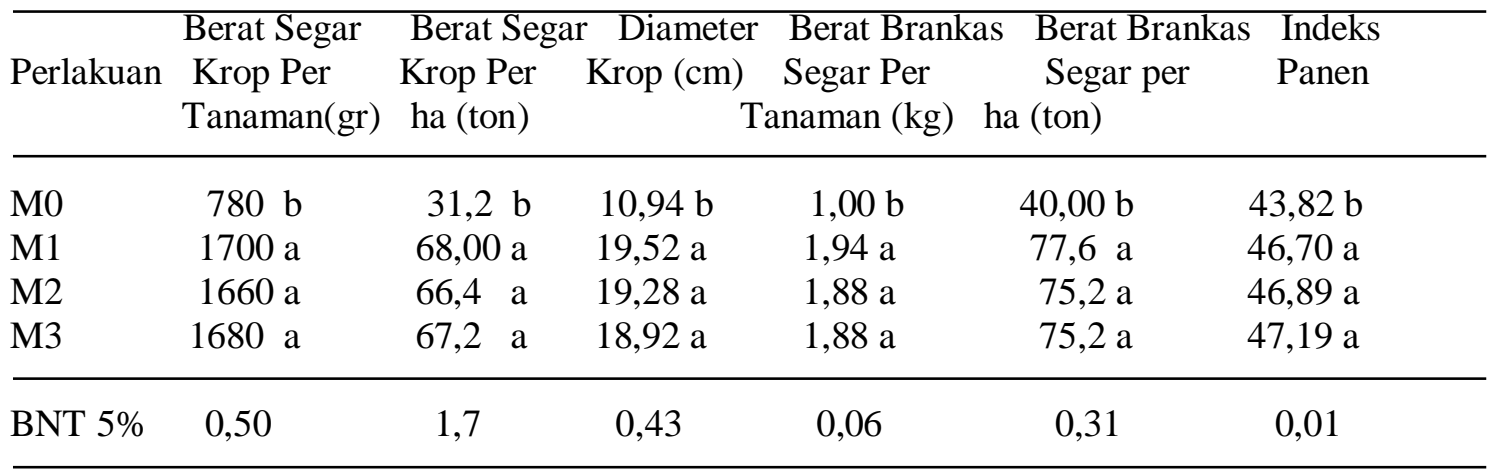

Keterangan : Angka yang diikuti oleh huruf yang sama pada kolom yang sama menunjukan tidak berbeda nyata pada taraf $5 \%$ uji BNT.

\section{Berat segar krop per tanaman.}

Rataan berat segar krop per tanaman pada tabel 4.3. menunjukan bahwa pada perlakuan M1, M2, dan M3, tidak berbeda nyata, namun berbeda nyata dengan perlakuan M0.
Pada tabel diatas menunjukan bahwa untuk perlakuan M0 yang tidak menggunakan MOL memberikan jumlah berat segar krop per tanaman, berat segar krop per ha, diameter krop, berat brangkasan segar per tanaman, serta indeks panen yang lebih rendah 
Murdaningsih: Pengaruh waktu pemberian mikro organisme lokal terhadap pertumbuhan dan hasil tanaman kubis (Brasicca oleraceae L.)

karena bahan organik dalam tanah lambat terurai akibat tidak adanya Mikro Organisme dari MOL yang bekerja merombak bahan organik tanah menjadi unsur hara $\mathrm{N}, \mathrm{P}, \mathrm{K}$, yang penting untuk pertumbuhan tanaman, sehingga hal ini sangat mempengaruhi hasil tanaman menjadi rendah. Sedangkan pada perlakuan M1 (3 hari sekali), M2 (5 hari sekali), dan M3 (7 hari sekali), tidak beda nyata pada jumlah berat segar krop per tanaman, berat segar krop per ha, diameter krop, berat segar brangkasan per tanaman, serta indeks panen, karena pada semua perlakuan ini disaat panen sudah diberikan banyaknya MOL yang sama banyak yaitu 14,4 liter/petak (5 petak = 72 liter) dan dosis tersebut diduga berlebihan sehingga, walapun waktu pemberianya yang berbeda, tapi akibat dari pemanfaatan MOL dengan dosis yang sama, sehingga kondisi tanah pada semua perlakuan sudah mempunyai banyak mikroorganisme yang sama jumlahnya dan tersedia mampu mempercepat proses perombakan bahan organik dalam tanah menjadi unsur hara $\mathrm{N}, \mathrm{P}, \mathrm{K}$, yang lengkap, dimana unsur $\mathrm{N}$ yang diperlukan tanaman selama fase vegetatif mempercepat pertumbuhan tinggi tanaman, jumlah daun, dan luas daun memungkinkan terjadinya proses fetosintesis yang lebih baik sehingga menghasilkan asimilat yang lebih tinggi untuk pertumbuhan tanaman kubis, unsur $\mathrm{P}$ yang diperlukan untuk memperbaiki perkembangan perakaran supaya berfungsi lebih maksimal menyerap unsur hara dalam tanah, dan unsur $\mathrm{K}$ yang dibutuhkan tanaman untuk pembentukan klorofil, dan pembentukan krop tanaman kubis (Jumin HB, 1995), sehingga dengan demikian semua perlakuan dapat meningkatkan jumlah berat segar krop per tanaman, berat segar krop per ha, diameter krop, berat brangkasan segar per tanaman, serta indeks panen pada setiap perlakuan menjadi lebih baik pada saat panen. Dengan melihat hasil dari perlakuan M1, perlakuan M2, dan perlakuan M3, hal ini tidak terbukti dengan hipotesis, sehingga hipotesis pertama dan hipotesis ke 2 ditolak.

\section{Simpulan.}

1. Waktu pemberian MOL berpengaruh terhadap pertumbuhan tanaman kubis, yaitu interval 3 hari sekali (perlakuan M1) memberikan jumlah daun pertanaman terbaik (11,72 helai daun), dimana pada umur 42 hst, untuk perlakuan M1 
Murdaningsih: Pengaruh waktu pemberian mikro organisme lokal terhadap pertumbuhan dan hasil tanaman kubis (Brasicca oleraceae L.)

mengalami

peningkatan

pertumbuhan jumlah daun sebesar 20,52\%, bila dibandingkan dengan perlakuan M0 (9,20 helai daun), pada perlakuan M2 mengalami peningkatan pertumbuhan jumlah daun sebesar 10,24\%, bila dibandingkan dengan perlakuan M0, dan pada perlakuan M3 mengalami peningkatan pertumbuhan jumlah daun sebesar $9,0 \%$ bila dibandingkan dengan perlakuan M0.

2. Waktu pemberian MOL tidak berpengaruh terhadap hasil tanaman kubis dimana perlakuan M1, M2, dan M3, tidak berbeda pada berat segar krop pertanaman, berat segar krop per hektar, diameter krop, berat segar brangkasan per tanaman dan indeks panen. Sehingga hipotesis pertama dan kedua ditolak karena dosis yang digunakan berlebihan.

\section{Ucapan Terima Kasih}

Pada kesempatan ini penulis ingin mengucapkan terima kasih kepada semua pihak yang telah membantu dengan caranya masing-masing dalam melengkapi tulisan ini.

\section{DAFTAR PUSTAKA}

Basri hasan, 2002. Agronomi. Penerbit Raja Grafindo Persada, Jakarta

Dinas Pertanian dan Tanaman Pangan Kab Ende. 2011. Data Produksi Kab. Ende

Gomez KA, Gomez A.A. 1995. Prosedur statistik untuk penelitian pertanian, edisi ke 2. Universitas Indonesia Jakarta.

Rahmat Rukmana. 1993. "Budidaya Broccoli di Dataran Menengah. “Bandung Pos, Jumat 23 Juli 1993.

Sitto Jakes. 2012. Teknik Pembuatan MOL (Mikro Organisme Lokal). noreply@blogger.com “selasa 12 Juni 2012".

Sitto Jakes. 2010. Aplikasi MOL Pada

Lingkungan. noreply@blogger.com "selasa 12 Juni 2012".

Sofa. 2008. Jenis MOL (Mikro Organisme Lokal). "Mitra Tani" Edisi Sabtu 24 April, 2008.

Suwardji. 2007. "Teknik Pemupukan Kubis Dataran Rendah” Sinar Baru, Bandung .

Zakaria. 2002. "Kandungan Kotoran Ternak Ayam" Sinar Baru, Bandung. 